\title{
PENERAPAN MODEL PEMBELAJARAN KOOPERATIF DALAM PENINGKATAN MOTIVASI, PARTISIPASI BELAJAR SERTA KREATIVITAS SISWA PADA MATA PELAJARAN GEOGRAFI DI KELAS X-1 SMA NEGERI 3 BAUBAU
}

\author{
Mujurimi \\ Dinas Pendidikan, Pemuda, dan Olahraga Kota Baubau, SMA Negeri 3 Baubau, \\ E-mail:mujurimi@gmail.com
}

\begin{abstract}
Abstrak
Penelitian Tindakan Kelas (PTK) bertujuan untuk meningkatkan motivasi dan partisipasi belajar siswa, untuk meningkatkan prestasi dan kreativitas belajar siswa dengan penggunaan model pembelajaran cooperative learning. Hasil penelitian menunjukkan bahwa proses pembelajaran dengan cooperative learning dapat meningkatkan motivasi dan partisifasi belajar sehingga dapat merubah paradigma belajar dari teacher centered ke student centered. Secara tidak langsung metode ini berhasil juga meningkatkan hasil atau prestasi belajar serta kreativitas siswa dalam belajar.
\end{abstract}

Kata kunci: cooperative learning, prestasi siswa.

\begin{abstract}
This research used classroom action research. The objective of this research was to increase the students' motivation and participation, to increase the students' achievement and creativity by using cooperative learning model. The result of this research showed that the study by using cooperative learning model could increase motivation and participation to learn so it could change study paradigm from teacher centered to student centered. Indirectly, this method was success to increase the achievement and the creativity of the students to learn.
\end{abstract}

Key words: cooperative learning, students' achievement. 


\section{SANG PENCERAH}

Volume 4, Nomor 1, Februari 2018, Hlm. 22-39

\section{Mujurimi: Penerapan Model Pembelajaran Kooperatif ...}

\section{Pendahuluan}

Pelajaran geografi merupakan rumpun pelajaran Ilmu Pengetahuan Sosial. Selama ini ada semacam anggapan bahwa belajar IPS termasuk geografi identik dengan hapalan, sehingga membosankan bagi siswa, apalagi dewasa ini siswa hanya menganggap bahwa mata pelajaran rumpun IPS kurang penting dibandingkan dengan rumpun IPA. Hal ini menyebabkan motivasi untuk belajarpun menjadi rendah. Situasi diatas membuat seorang guru seringkali tidak bersemangat mengajar karena melihat anak didiknya tidak mau belajar dan ternyata masalahnya adalah anak didik tidak memiliki motivasi atau daya penggerak dalam belajar. Menghadapi situasi yang demikian, guru yang propesional harus menyadari bahwa semangat dan gairah belajar siswa tidak hanya ditentukan oleh anak didik itu sendiri, akan tetapi dirinya juga harus ikut berperan sebagai motivator.

Sehubungan dengan hal tersebut seorang guru dituntut untuk menggunakan strategi pembelajaran yang bervariasi, sehingga dapat melayani perbedaan individual siswa, mengaktifkan siswa dengan guru, mendorong berkembangnya kemampuan baru, yang ada akhirnya siswa memiliki motivasi belajar yang tinggi. Hal ini seiring dengan pergeseran paradigma pendidikan yang berubah dari pola teaching (mengajar) ke learning (belajar). Oleh karena itu seorang guru sebagai pendidik perlu memiliki berbagai metodologi mengajar, karena keberhasilan Proses Belajar Mengajar (PBM) bergantung pada cara/mengajar gurunya. Jika cara mengajar gurunya enak maka siswa akan tekun, rajin, antusias menerima pelajaran yang diberikan sehingga diharapkan akan terjadi perubahan dan tingkah laku pada siswa baik tutur katanya, sopan santunnya, motorik maupun gaya hidupnya

Rendahnya motivasi dan partisifasi belajar dirasakan di SMA Negeri 3 Baubau. Hal ini terlihat ketika guru menjelaskan materi pelajaran, tampak siswa kurang tertarik mengikuti pembelajaran yang diberikan oleh guru. Hal ini terlihat dari indikasi adanya beberapa orang siswa yang tidak serius sewaktu mendengarkan penjelasan guru seperti membuat tulisan-tulisan yang tidak berkaitan dengan materi pelajaran, berbisik-bisik dengan temannya atau bahkan kelihatan mengantuk. Perilaku tersebut tentunya berakibat pada rendahnya pemahaman siswa terhadap materi pelajaran Geografi, sehingga prestasinyapun menjadi rendah.

Kondisi tersebut salah satunya mungkin disebabkan oleh metode mengajar yang digunakan oleh guru, atau kurangnya media pembelajaran dan kurangnya guru dalam mengembangkan bahan pembelajaran. Guru hanya menggunakan metode ceramah, dengan diselingi tanya jawab yang minim, sehingga hal ini membuat siswa cepat bosan dan kurang terlibat dalam kegiatan pembelajaran. Kondisi demikian akan teratasi manakala guru berupaya untuk menentukan solusinya, yaitu mengganti model pembelajaran yang selama ini sering di gunakan. Salah satu model pembelajaran yang dipandang mampu mengatasi permasalahan belajar siswa di atas adalah model pembelajaran kelompok dengan strategi pembelajaran kooperatif (cooperative learning). Model pembelajaran ini berangkat dari dasar pemikiran "getting better together" yang menekankan pada pemberian kesempatan belajar yang lebih luas dan suasana yang kondusif. Strategi 


\section{SANG PENCERAH}

Volume 4, Nomor 1, Februari 2018, Hlm. 22-39

\section{Mujurimi: Penerapan Model Pembelajaran Kooperatif ...}

pembelajaran kooperatif merupakan strategi pembelajaran kelompok yang akhir-akhir inipe dianjurkan oleh para ahli. Menurut Slavin dalam Sanjaya (2006) mengemukakan dua alasan tentang pembelajaran kooperatif, pertama beberapa hasil penelitian membuktikan bahwa penggunaan pembelajaran kooperatif dapat meningkatkan prestasi siswa sekaligus dapat meningkatkan hubungan sosial, menumbuhkan sikap menerima kekurangan diri dan orang lain serta dapat meningkatkan harga diri. Kedua, pembelajaran kooperatif dapat memecahkan masalah dan mengintegrasikan pengetahuan dengan keterampilan. Dengan demikian pembelajaran kooperatif memiliki dampak yang positif terhadap siswa yang rendah hasil belajarnya, karena dapat meningkatkan motivasi, hasil belajar dan penyimpanan materi pelajaran yang lebih lama. Berdasarkan uraian di atas, fokus penelitian ini adalah bagaimana penerapan model pembelajaran kooperatif dalam peningkatan motivasi, partisipasi belajar serta kreativitas siswa pada mata pelajaran Geografi di kelas $X$ SMA Negeri 3 Baubau.

Tujuan penelitian ini untuk mengetahui efektifitas penerapan model pembelajaran kooperatif dalam peningkatan motivasi, partisipasi belajar serta kreativitas siswa pada mata pelajaran Geografi di kelas $X$ SMA Negeri 3 Baubau.

\section{Metode Penelitian}

Penelitian ini dilaksanakan di kelas X-1 SMA Negeri 3 Baubau pada materi geografi semester 2. Siswa kelas terdiri dari laki-laki 22 orang dan perempuan 16 orang. Jumlah siswa secara keseluruhan adalah 38 orang.
Dipilihnya kelas $X-1$ sebagai tempat penelitian karena diasumsi bahwa bahwa kelas ini telah memiliki kemampuan dasar keterampilan kooperatif seperti mengajukan pertanyaan, menjawab pertanyaan/menanggapi,

menyampain pendapat/ide, mendengarkan secara aktif, berada dalam tugas dan sebagainya, dalam kegiatan belajar sebelumnya.

Penelitian ini menggunakan rancangan penelitian Kelas (classroom based action research) dengan peningkatan pada unsur motivasi dan prestasi belajar prestasi belajar serta kreativitas siswa, untuk memungkinkan ditemukan dan diperolehnya efektivitas tindakan yang dilakukan. Konsep yang dipilih sebagai acuan peningkatan motivasi dan partisifasi belajar dalam mata pelajaran geografi adalah keberanian siswa untuk bertanya atau menjawab, sedangkan acuan peningkatan prestasi belajar dalam mata pelajaran geografi adalah hasil akhir nilai kognitif siswa yang harus mencapai ketuntasan. Data penelitian dikumpulkan melalui observasi dan catatan lapangan. Observasi dilakukan untuk mengetahui, motivasi, dan hasil belajar siswa dalam pembelajaran geografi sesuai dengan Rencana Pelaksanaan Pembelajaran (RPP) yang telah dirancang. Adapun catatan lapangan dilakukan untuk menggali aspekaspek lainnya yang diperlukan dalam penelitian tindakan kelas ini.

Penelitian tindakan kelas dilaksanakan dengan tahapan perencanaan, tindakan, observasi, dan evaluasi/refleksi dan disajikan dalam dua siklus. Data dikumpulkan, kemudian dipetakan dan dianalisis bersama mitra kolaborasi sejak penelitian tindakan dimulai. Selanjutnya data dikembangkan selama proses refleksi sampai proses 


\section{SANG PENCERAH}

Volume 4, Nomor 1, Februari 2018, Hlm. 22-39

\section{Mujurimi: Penerapan Model Pembelajaran Kooperatif ...}

penyusunan laporan. Teknis analisis data yang digunakan adalah model alur, yaitu reduksi data, penyajian data, dan penarikan kesimpulan (Miles \& Huberman, 1989)

Dalam penelitian ini terdapat beberapa aspek yang menjadi fokus untuk diteliti. Aspek-aspek tersebut yaitu (1) Siswa meliputi (a) Keaktifan; (b) Motivasi; (c) Kreativitas (d) Hasil belajar; (2) Guru meliputi (1) model pembelajaran kelompok dengan strategi pembelajaran kooperatif. Untuk mendapatkan data penelitian yang valid dan dapat dipertangungjawabkan, maka dalam dalam penelitian ini digunakan beberapa instrumen pembantu, yaitu lembar observasi, dan lembar hasil tes siswa.

Dalam penelitian ini aspek yang diteliti adalah siswa dan guru, oleh karena itu yang menjadi indikator kinerja adalah perubahan yang terjadi pada siswa baik dalam proses pembelajaran maupun dalam hasil belajar. Sebagai indikator keberhasilan adalah siswa memiliki motivasi belajar yang tinggi dalam belajar dengan menunjukkan keaktifan dalam belajar kelompok, sehingga hasil belajarpun akan meningkat. Sedangkan indikator kinerja bagi guru adalah adanya perubahan model pembelajaran yang variatif yang salah satunya adalah dengan strategi pembelajaran kooperatif, yang diharapkan dapat meningkatkan motivasi dan hasil belajar siswa.

\section{Pembahasan}

\section{Pelaksanaan Tindakan Siklus I a. Perencanaan}

Tindakan siklus I dilaksanakan pada awal bulan Januari selama 2 minggu atau 2 pertemuan. Kegiatan-kegiatan yang dilakukan pada tahap perencanaan tindakan siklus I ini adalah penyusunan persiapan mengajar model pembelajaran cooperatif learning. Sebelum pelaksanaan tindakan atau siklus-siklus berlangsung maka berdasarkan temuan selama pembelajaran geografi terdapat kekurangan keterlibatan siswa dalam pembelajaran, dan siswa menjadi pasif sehingga berpengaruh terhadap hasil belajar yang diharapkan. Hal ini terjadi karena pembelajaran yang dikembangkan cenderung satu satu arah yaitu berpusat pada guru (teacher centered), sedangkan siswa hanya menjadi pendengar dan hanya mencatat apa yang telah disampaikan guru di depan kelas. Kondisi ini membuat siswa menjadi pasif dan motivasi untuk belajar sangat rendah, mereka terlihat mengantuk dan prestasi belajar yang diinginkanpun menjadi relatif rendah.

Dalam kondisi demikian maka kami membuat kesepakatan untuk merubah model pembelajaran yaitu dengan cooperatif learning yang diharapkan dapat melibatkan siswa lebih banyak dalam pembelajaran. Tahap perencanaan dalam model pembelajaran kooperatif dilakukan dengan berembug untuk membuat persiapan mengajar yang mencakup masalah-masalah dan langkahlangkah pembelajaran yang akan dilaksanakan yang mencerminkan model pembelajaran cooperatif learning. Sebelum pelaksanaan pembelajaran, kami juga terlebih dahulu membentuk kelompok siswa berdasarkan heterogenitas, baik jenis kelamin, prestasi akademik dan tingkah laku serta keberanian siswa. Hasilnya dari 38 siswa terentuk 8 kelompok yang terdiri dari $4-5$ orang. Rencana masalah 


\section{SANG PENCERAH}

Volume 4, Nomor 1, Februari 2018, Hlm. 22-39

\section{Mujurimi: Penerapan Model Pembelajaran Kooperatif ...}

yang akan diangkat dalam diskusi dan sesekali memberikan pembelajaran cooperatif learning pada tindakan siklus I adalah masalah persebaran flora maupun fauna di permukaan bumi yang terkait dengan faktor-faktor yang mempengaruhinya.

\section{b. Pelaksanaan}

Tahap selanjutnya, kami mencoba menerapkan model cooperatif learning yang melibatkan siswa dalam pembelajaran. Sebelum guru menjelaskan materi pada hari itu, terlebih dahulu memberikan pre tes untuk melihat kemampuan awal siswa sebelum dilaksananan pembelajaran model cooperative learning. Langkah selanjutnya yang dilakukan oleh guru adalah menjelaskan materi secara umum dari biosfer, diantaranya tentang pengertian biosfer, bioma, habitat, biotope dan biosiklus. Dijelaskan pula tentang faktor-faktor yang dapat mempengaruhi persebaran flora di permukaan bumi.

Setelah selesai kemudian meminta siswa untuk duduk sesuai dengan kelompok yang telah ditentukan, untuk mendiskusikan LKS yang akan diberikan guru pada tiap kelompok. Sebelum mereka berdiskusi guru memberikan penjelasan bahwa dengan belajar kelompok dan berdiskusi sesama teman belajar akan menjadi lebih mudah mengerti, bisa saling membantu, saling menghargai dan pekerjaan yang dianggap sulitpun akan mudah diselesaikan kalau dikerjakan secara bersama-sama. Setelah guru memberi penjelasan siswa tampak mulai bekerja menyelesaikan tugas yang telah diberikan. Sementara siswa sedang sibuk melaksanakan pekerjaan di kelompoknya, maka tindakan guru selanjutnya mengawasi jalannya arahan bekerja dalam kelompok. Diskusi berjalan sampai dengan batas waktu yang telah ditentukan, dan setelah itu guru menutup pembelajaran dengan meminta siswa masing-masing kelompok untuk maju ke depan mempresentasikan hasil diskusinya. Setelah semua kelompok maju, maka tahap akhir pembelajaran diakhiri dengan memberikan post test.

\section{c. Refleksi dan Revisi}

Hasil evaluasi sesuai dengan pengamatan peneliti selama pelaksanaan siklus I berlangsung, maka pada dasarnya guru sudah menerapkan langkah-langkah pengembangan bahan ajar dengan melibatkan siswa dalam kegiatan pembelajaran. Namun belum seperti yang dikehendaki karena beberapa hal baik cara guru maupun prilaku siswa masih belum sesuai harapan. Hai ini terlihat dari hasil observasi bahwa ketika guru menjelaskan materi biosfer secara umum diawal pembelajaran kurang memberikan contoh-contoh kongkrit, sehingga kurang menimbulkan motivasi dan keingintahuan siswa terhadap hal yang dijelaskan.

Selain itu hasil observasi
juga menunjukkan bahwa pemantauan guru terhadap jalannya diskusi kelompok masih kurang. Dalam proses pembelajaran juga terlihat masih banyaknya dominasi guru sedangkan siswa masih kurang aktif. Saat diskusi berlangsung hanya siswa yang memiliki prestasi akademik tinggi yang lebih aktif berdiskusi, sedangkan yang lain masih ada yang bermain-main dan bercanda, yang hanya akan terhenti bila 


\section{SANG PENCERAH}

Volume 4, Nomor 1, Februari 2018, Hlm. 22-39

Mujurimi: Penerapan Model Pembelajaran Kooperatif ...

ditegur oleh guru. Aspek kerjasama juga belum terlihat maksimum. Siswa yang pintar kurang berusaha membimbing siswa yang kurang dan hanya bertanggung jawab pada pekerjaannya saja. Sedangkan di sisi lain mereka yang kurang secara akademik juga seperti kurang peduli dengan permasalahan yang seharusnya dipecahkan secara bersama.

Selain itu dalam diskusi juga terlihat kurangnya rasa untuk menghargai orang lain, mereka yang pintar lebih mendominasi dan menyepelekan mereka yang secara akademik lebih rendah sehingga membuat mereka menjadi minder dan kurang percaya diri untuk berpendapat. Sementara itu penghargaan guru bagi siswa yang aktif dalam diskusi berupa pujian juga masih kurang, sehingga siswa yang secara akademik lebih rendah kurang termotivasi untuk ikut aktif dalam diskusi. Kreatifitas siswa pada siklus I ini juga belum nampak, sementara gurupun kurang memberikan arahan pada siswanya untuk menciptakan alat peraga dalam pemebelajaran. Berikut ini adalah hasil observasi yang dilakukan peneliti pada guru dan siswa pada pelaksanaan tindakan siklus I.

Tabel 1. Hasil Observasi Kemampuan Guru Dalam Pengembangan Bahan Ajar.

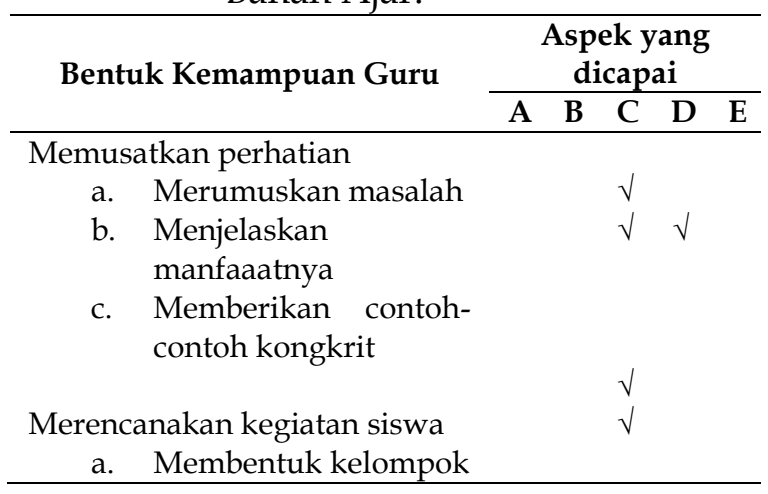

b. Menjelaskan langkah-

langkah kerja

Mengembangakan kemampuan siswa

a. Memeberikan

keleluasaan waktu

kepada siswa

mengembangkan

kemampuannya.

b. Tidak cepat

memotong

pembicaraan

Meningkatkan motvasi siswa

a. Memberikan pujian terhadap individu atau kelompok yang berprestasi

Menyebarkan kesempatan berpartisipasi

a. Mengontrol aktivitas siswa

b. Mencegah pembicaraan yang berlebihan

c. Menghentikan monopoli pembicaraan

Menutup diskusi

a. Merangkum/menyim pulkan

b. Memberi gambaran materi yang akan datang

Keterangan:

$\mathrm{A}=$ seringkali dilakukan

$\mathrm{B}=$ sering dilakukan

$\mathrm{C}=$ kadang-kadang dilakukan

$\mathrm{D}=$ jarang dilakukan

$\mathrm{E}=$ jarang sekali dilakukan

Selain itu hasil pengamatan terhadap prilaku siswa yang dilakukan oleh guru dan peneliti pada siklus I ini juga dapat dilihat dalam hasil observasi berikut ini. 


\section{SANG PENCERAH}

Volume 4, Nomor 1, Februari 2018, Hlm. 22-39

Mujurimi: Penerapan Model Pembelajaran Kooperatif ...

Tabel 2. Hasil Obser
siswa selam
Bentuk Kemampuan
Guru
Kerjasama
a. Memeberikan
bantuan terhadap
temannya
b. Melaksanakan
tugas
c. Ikut berperan

Kepemimpinan

a. Mengabsen anggota kelompok

b. Memberi tugas

c. Membuka diskusi

d. Menutup diskusi

e. Memberikan kesempatan berbicara kepada peserta secara adil.

f. Mengajukan pertanyaan

g. Mengajukan saran atau pendapat

Mengembangakan nilai-nilai demokratis
a. Tidak berbicara
saat orang
berbicara
b. Memberikan
kesempatan pada
orang lain untuk
mengemukakan
pendapat
c. Tidak
menyalahkan
cecara langsung
apabila ad aide
yang kurang tepat
d. Menyelesaikan
tugas tepat waktu

Menghasilkan kreativitas

a. Media pembelajaran yang dapat dipakai di kelas.

b. Media pembelajaran untuk digunakan sendiri oleh siswa.
Keterangan:

A $=$ seringkali dilakukan

$\mathrm{B}=$ sering dilakukan

$\mathrm{C}=$ kadang-kadang dilakukan

$\mathrm{D}=$ jarang dilakukan

$\mathrm{E}=$ jarang sekali dilakukan

Indikator peningkatan motivasi belajar ini juga terlihat dari adanya peningkatan nilai rata-rata tiap kelompok dari sebelum menggunakan pembelajaran kooperatif dengan sesudah pembelajaran kooperatif dimana sebelumnya hasil pre tes ratarata nilai kelas adalah 41, maka setelah pembelajaran kooperatif hasil post test meningkat manjadi 60,5 . yang berarti mendekati nilai kriteria ketuntasan minimal. Rekap nilai rata-rata tiap kelompok terliahat pada tabel berikut ini.

Tabel 3. Rekapitulasi Perbandingan Pretes dan Post tes Hasil Belajar Siswa Secara Individual Pada Siklus 1

\begin{tabular}{cccc}
\hline \multirow{2}{*}{ Kelompok } & \multicolumn{2}{c}{$\begin{array}{c}\text { Skor jawaban } \\
\text { Siswa }\end{array}$} & \multirow{2}{*}{ Ket. } \\
\cline { 2 - 3 } & Pretest & Post Tes & \\
\hline I & 44 & 55 & Batas \\
II & 45 & 63 & tuntas 66 \\
III & 39 & 60 & \\
IV & 48 & 67 & \\
V & 39 & 58 & \\
VI & 45 & 66 & \\
VII & 40 & 56 & \\
VIII & 42 & 59 & \\
\hline Jumlah & 342 & 484 & \\
\hline Rata-rata & 42,75 & 60,5 & \\
\hline
\end{tabular}

\section{d. Refleksi}

Berdasarkan hasil evaluasi dari hasil observasi atau pengamatan selama implementasi berlangsung pada siklus I, terdapat beberapa hal yang dapat diajukan sebagai perbaikan dalam siklus kedua sebagai hasil refleksi dari siklus I. Pada dasarnya langkah-langkah pembelajaran kooperatif yang diterapkan oleh guru sudah 


\section{SANG PENCERAH}

Volume 4, Nomor 1, Februari 2018, Hlm. 22-39

\section{Mujurimi: Penerapan Model Pembelajaran Kooperatif ...}

melibatkan siswa dalam

pembelajaran sehingga tidak lagi bersifat teacher centered. Namun dalam pelaksanaan masih ada beberapa hal yang harus diperbaiki yaitu:

a. Dalam penjelasan materi di awal disarankan lebih banyak memberikan contoh-contoh kongkrit, sehingga dapat memotivasi keingintahuan siswa dan bersemangat untuk mencari tahu lebih banyak

b. Selama diskusi kelompok berlangsung, guru harus lebih intensif lagi memantau siswa sehingga siswa yang masih bermain-main dalam diskusi dapat berubah untuk lebih aktif belajar.

c. Motivasi belajar yang sudah meningkat perlu diarahkan untuk semua siswa dengan selalu memberi reward berupa pujian atau bahkan nilai bagi setiap siswa yang ikut aktif memberi masukan dalam diskusi kelompok sehingga dapat memotivasi semua siswa untuk aktif, dan diskusi kelompok bukan hanya milik siswa yang secara akademik lebih tinggi.

d. Kerjasama dalam kelompok juga perlu terus dimotivasi dengan cara menekankan kepada semua siswa yang secara akademik lebih tinggi, bahwa kelompok yang dianggap berhasil mendapatkan nilai baik adalah kelompok yang kompak, dapat bekerjasama dengan sesama anggotanya, bukan bekerja masing-masing, sehingga diharapkan terjalin kerjasama untuk saling memberi dan menerima, dan selalu menghargai semua pendapat meskipun salah. Hal ini akan membuat siswa yang secara akademik rendah lebih berani untuk berpendapat.

\section{Pelaksanaan Tindakan Siklus II}

\section{a. Perencanaan}

Rencana pengajaran yang perlu mendapat perhatian adalah penentuan tugas yang harus dilakukan siswa dalam kerjasama kelompok harus disesuaikan dengan alokasi waktu, pola interaksi yang dilakukan oleh guru masih bersifat satu arah sehingga siswa tampak pasif, metode penyampaian materi lebih variatif, guru lebih aktif melakukan pengawasan terhadap jalannya diskusi diantara siswa dalam kelompoknya. Selain itu guru harus lebih banyak memberikan penguatan setiap hasil kerja siswa, baik individu maupun kelompoknya. Untuk tindakan kedua dalam pengembangan model cooperative learning telah dirancang pembelajaran sebagai berikut:

\section{b. Pelaksanaan dan Observasi}

Berdasarkan revisi pembelajaran yang telah disepakati antara guru dan rekan peneliti, maka tindakan kedua ini dilaksanakan pada pertengahan Februari 2012. Langkah pertama guru mengabsen sisa satu persatu, ternyata siswa pada hari itu hadir seluruhnya. Setelah guru selesai mengabsen siswa, dilanjutkan dengan pembagian pre tes dengan maksud untuk mengukur sejauh mana kemampuan siswa secara kognitif dalam hal penguasaan terhadap materi yang akan diajarkan. Selanjutnya barulah guru menjelaskan pembelajaran yang akan dibahas pada hari itu, dengan menggunakan metode ceramah guru menjelaskan secara singkat persebaran flora dan fauna di dunia dan di Indonesia yang disertai dengan menunjukkan pada gambar dan peta. Beberapa siswa tampak 


\section{SANG PENCERAH}

Volume 4, Nomor 1, Februari 2018, Hlm. 22-39

\section{Mujurimi: Penerapan Model Pembelajaran Kooperatif ...}

serius mendengarkan penjelasan guru, namun ada juga siswa yang acuh karena memang guru tidak memberikan pertanyaan yang memancing siswa dalam pembelajaran. Setelah guru menjelaskan materi pelajaran secara singkat, barulah guru memberikan pertanyaan secara lisan kepada siswa tentang apa yang dijelaskannya. Pertemuan sebelumnya guru telah meminta siswa untuk membawa peralatan yang dapat menggambarkan persebaran flora dan fauna di dunia.

Kegiatan guru selanjutnya adalah menyuruh siswa duduk berdasarkan kelompok yang telah dibentuk sebelumnya. Pembentukan kelompok ini pun telah diatur oleh guru atas dasar karakteristik siswa sebagaimana yang telah dijelaskan oleh pengamat/peneliti sebelumnya. Tampak guru dapat memahami apa yang telah diterimanya dari peneliti. Setelah siswa duduk dengan tertib sesuai dengan kelompoknya masing-masing, guru kembali menjelaskan kepada siswa tentang manfaat dan keuntungan yang akan diperoleh dalam belajar dengan model cooperative learning. Pekerjaan yang berat dapat menjadi ringan karena dikerjakan bersamasama, sehingga hasilnya akan lebih baik dibandingkan dengan hasil yang dikerjakansecara sendirisendiri. Kemudian siswa dipersilahkan oleh guru untuk melakukan diskusi pada kelompoknya masing-masing sesuai dengan ptunjuk yang telah diberikan guru.

Setelah diskusi kelompok selesai, saat presentasi di depan kelas tampak ketua kelompok sudah melaksanakan tugasnya dengan baik yaitu sebelum membacakan hasil diskusinya terlebih dahulu memperkenalkan anggota kelompoknya, dan menyebutkan pembagian tugas masing-masing. Hal ini menunjukan bahwa kelompok tersebut telah mampu mengembangkan nilai-nilai demokrasi yang dikehendaki dalam model pembelajaran cooperative learning. Namun masih ada satu kelompok yang belum dapat mengembangkan nilai-nilai demokrasi dalam kelompoknya yaitu kelompok enam.

Setelah selesai dilanjutkan dengan membuat beberapa kretifitas yang dapat menggambarkan persebaran flora dan fauna didunia dan di Indonesia. Mereka sebelumnya bertanya kepada guru apakah kelompoknya boleh membuat sutu kreatifitas tertentu, dan guru memotivasi dengan mempersilahkan buat dalam bentuk apapun, sesuai dengan kemauan. Karena keterbatasan waktu maka kreatifiatas siswa dilanjutkan di rumah oleh masing-masing kelompok.

\section{c. Refleksi}

Kegiatan pembelajaran dengan menggunakan model cooperative learning pada tindakan kedua ini sudah cukup baik. Halhal yang dianggap kurang baik pada tindakan pertama, seperti bagaimana guru membuka pelajaran, teknik bertanya, teknik pembentukan kelompok, penjelasan manfaat/ keuntungan dan prosedur pelaksanaan model pembelajaran cooperative learning telah diperbaiki sebagaimana yang diharapkan peneliti. Walaupun kelemahan dan kekurangan sebelumnya telah 


\section{SANG PENCERAH}

Volume 4, Nomor 1, Februari 2018, Hlm. 22-39

\section{Mujurimi: Penerapan Model Pembelajaran Kooperatif ...}

diperbaiki tidak berarti proses pembelajaran sudah baik, karena masih terdapat kelemahan yang perlu diperhatikan. Guru telah berhasil menempatkan dirinya sabagai motivador, fasilitator, mediator dan dinamisator dalam proses pembelajaran sehingga dapat memotivasi dan mengarahkan siswanya untuk memperbaiki kelemahankelemahan yang telah dilakukan sebelumnya, terutama dalam pelaksanaan diskusi.

Dalam hal kegiatan membuka pelajaran, guru telah mampu memberikan penjelasan mengenai sub pokok bahasan yang akan dipelajari, dan telah pula dihubungkan dengan materi pembelajaran sebelumnya. Disamping itu guru sudah cukup baik dalam menghidupkan suasana kelas dengan menjelaskan materi pelajaran yang mengkombinasikan berbagai metode mengajar seperti ceramah dan tanya jawab. Guru telah menjalankan fungsinya sebagai seorang pengembang kurikulum, hal ini dibuktika dari penyajian materi yang tidak lagi memakai satu buku sebagai sumber relajar, Namur ada lagi buku-buku lain yang digunakan. Media peta untuk mempermudah pemahaman siswa juga mulai berfungsi dengan baik.

Dalam kagiatan inti, khususnya yang berkenaan dengan aspek-aspek kerjasama, aspek kepemimpinan dan penanaman nilai-nilai demokrasi telah sesuai dengan yang diharapkan, walaupun masih terdapat kelemahan yakni masih adanya siswa yang kurang mengargai temannya yang sedang berbicara walaupun sudah dilarang oleh ketua kelompoknya. Selain itu masih adanya satu kelompok yang masih belum menunjukan kepemimpinan ketua kelompoknya dalam proses diskusi, misalnya dalam membacakan atau mempresentasikan hasil belum menyebutkan pembagian tugas individu dalam jelompoknya.

Kemudian aspek yang agak lemah dalam pelaksanaan tindakan kedua ádalah masalah efisiensi waktu. Hal ini terlihat dari lambatnya penyelesaian tugastugas kelompok, padahal jatah waktu yang diberikan oleh guru untuk berdiskusi telah habis, Namur masih ada kelompok yang menyelesaikan tugasnya dengan terburu-buru, walaupun guru telah berulang kali mnyebutkan bahwa waktu telah habis menandakan pengerjaan kelompok pun harus dihentikan, karena harus dilanjutkan dengan presentasi kelompok. Dalam hal menutup pelajaran, guru telah melakukannya dengan baik, yaitu dengan membuat beberapa kesimpulan dari materi pelajaran yang telah dipelajari. Kegiatan ini tentunya sangat penting dilakukan oleh guru supaya masalah-masalah intisari materi pelajaran akan lebih mudah diingat dan dimengerti oleh siswa.

Pemberian penghargaan atau reward oleh guru terhadap siswasiswa baik secara individu maupun kelompok sudah cukup tinggi, baik verbal dengan lisan seperti mengucapkan "baik, bagus, ya" maupun dengan kode-kode non verbal seperti menganggukan kepala, mengacungkan cap jempol dan lain-lain. Berikut ádala hasil pengamatan pada siklus II. 


\section{SANG PENCERAH}

Volume 4, Nomor 1, Februari 2018, Hlm. 22-39

Mujurimi: Penerapan Model Pembelajaran Kooperatif ...

Tabel 4. Hasil Observasi Kemampuan Guru Dalam Pengembangan Bahan Ajar

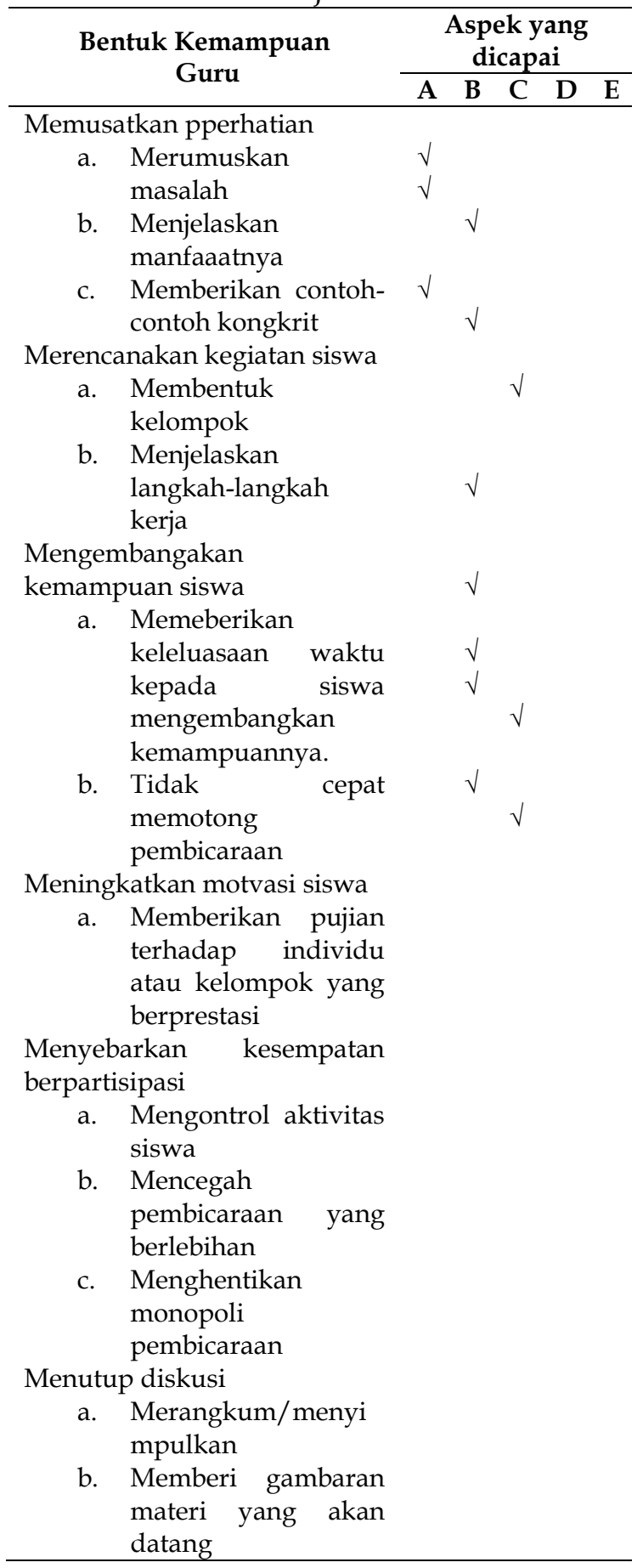

Keterangan:

$\mathrm{A}=$ seringkali dilakukan

$\mathrm{B}=$ sering dilakukan

$\mathrm{C}=$ kadang-kadang dilakukan

$\mathrm{D}=$ jarang dilakukan

$\mathrm{E}=$ jarang sekali dilakukan
Tabel 5. Hasil Observasi Partisipasi Siswa Selama Pembelajaran

\begin{tabular}{cccccc}
\hline \multirow{2}{*}{$\begin{array}{c}\text { Bentuk Kemampuan } \\
\text { Guru }\end{array}$} & \multicolumn{4}{c}{$\begin{array}{c}\text { Aspek yang } \\
\text { dicapai }\end{array}$} \\
\cline { 2 - 5 } & A & B & C & D & E \\
\hline
\end{tabular}

\begin{aligned} \hline Kerjasama & \\ a. & Memeberikan \\ & bantuan terhadap \\ & temannya \\ b. & Melaksanakan \\ & tugas \\ c. & Ikut berperan \end{aligned}

Kepemimpinan
a. Mengabsen anggota kelompok
b. Memberi tugas
c. Membuka diskusi
d. Menutup diskusi
e. Memberikan
kesempatan berbicara kepada peserta secara adil.
f. Mengajukan pertanyaan
g. Mengajukan sarn atau pendapat

Mengembangakan nilainilai demokratis
a. Tidak berbicara saat orang berbicara
b. Memberikan kesempatan pada orang lain untuk mengemukakan pendapat

c. Tidak menyalahkan cecara langsung apabila ad aide yang kurang tepat

d. Menyelesaikan tugas tepat waktu

Menghasilkan kreativitas
a. Media pembelajaran yang dapat dipakai di kelas.
b. Media pembelajaran untuk digunakan sendiri oleh siswa.




\section{SANG PENCERAH}

Volume 4, Nomor 1, Februari 2018, Hlm. 22-39

\section{Mujurimi: Penerapan Model Pembelajaran Kooperatif ...}

Keterangan :

A = seringkali dilakukan

$\mathrm{B}=$ sering dilakukan

$\mathrm{C}=$ kadang-kadang dilakukan

$\mathrm{D}=$ jarang dilakukan

$\mathrm{E}=$ jarang sekali dilakukan

Indikator peningkatan motivasi belajar ini juga terlihat dari adanya peningkatan nilai rata-rata tiap kelompok dari siklus tindakan I dan kedua pembelajaran kooperatif pada siklus I, hasil pre tes rata-rata nilai kelas adalah 41, maka setelah pembelajaran kooperatif hasil post test meningkat manjadi 60,5 . yang berarti mendekati nilai kriteria ketuntasan minimal. Rekap nilai rata-rata tiap kelompok terliahat pada tabel berikut ini.

Tabel 6. Rekapitulasi Perbandingan Pretest dan Post test Hasil Belajar Siswa Secara Individual Pada Siklus 2

\begin{tabular}{cccc}
\hline & \multicolumn{2}{c}{$\begin{array}{c}\text { Skor } \\
\text { Jawaban }\end{array}$} & \\
Kelompok & \multicolumn{2}{c}{ Siswa } & \multirow{2}{*}{ Ket. } \\
\cline { 2 - 3 } & $\begin{array}{c}\text { Pre } \\
\text { test }\end{array}$ & $\begin{array}{c}\text { Post } \\
\text { Test }\end{array}$ & \\
\hline I & 39 & 63 & Batas tuntas \\
II & 40 & 65 & 66 \\
III & 47 & 62 & \\
IV & 42 & 64 & \\
V & 39 & 68 & \\
VI & 44 & 67 & \\
VII & 39 & 56 & \\
VIII & 45 & 70 & \\
\hline Jumlah & 360 & 515 & \\
\hline Rata-rata & 45 & 64,38 & \\
\hline
\end{tabular}

\section{Pelaksanaan Tindakan Siklus III}

\section{a. Perencanaan}

Rencana pembelajaran yang dibuat pada siklus ketiga dirembugkan oleh peneliti dengan berpedoman pada kekurangan sebagai hasil refleksi dalam pembelajaran siklus II. Rencana pembelajaran yang mendapatkan fokus perhatian adalah penentuan tugas LKS yang harus dikerjakan siswa dalam diskusi kelompok disesuaikan dengan waktu yang tersedia, penyampaian materi lebih variatif dengan memberikan banyak contoh kongkrit untuk memotivasi keingintahuan siswa pada materi pelajaran yang dapat dilakukan dengan mengoptimalkan penggunaan media peta dan media lainnya. Dalam pelaksanaan diskusi guru lebih aktif melakukan pengawasan terhadap jalannya diskusi diantara siswa dalam kelompoknya. Selain itu pemberian reward berupa pujian atau penilaian kepada siswa yang aktif selalu dilakukan. Di akhir proses pembelajaran guru berusaha banyak memberikan penguatan setiap hasil kerja siswa, dan selalu membuat kesimpulan akhir dari materi pelajaran yang sudah didiskusikan oleh siswa.

\section{b. Pelaksanaan dan Observasi}

Pembelajaran pada sikslus ketiga langkah-langkah pelaksanannya sama seperti siklus pertama, tetapi ditiap langkah terjadi revisi untuk mengoptimalkan model pembelajaran kooperatif. Siklus ketiga ini dilaksanakan pada pertengahan bulan Februari 2012. Pelaksanaan pembelajaran pada siklus ketiga dilakukan dengan terlebih dahulu memberikan pretest. Selanjutnya barulah guru menjelaskan materi yang sudah sampai pada pembahasan tentang antroposfer, dengan terlebih dahulu mengajukan pertanyaan untuk memancing siswa terkait dengan gejala kependudukan yang bisan disaksikan siswa dalam kehidupanya. Penjelasan guru tentang antroposfer yakni gejala kependudukan terlihat lebih variatif 


\section{SANG PENCERAH}

Volume 4, Nomor 1, Februari 2018, Hlm. 22-39

\section{Mujurimi: Penerapan Model Pembelajaran Kooperatif ...}

dengan diselingi tanya jawab dengan siswa. Selain itu pemberian dalam penjelasannya selalu memberi contoh-contoh konkrit yang dapat dipahami siswa. Dalam penjelasannya guru selalu menunjukan lokasi yang dijelaskan dalam sebuah peta, dan hal ini menjadi daya tarik tersendiri bagi siswa.

Setelah penjelasan materi secara singkat, langkah berikutnya kembali guru meminta siswa untuk duduk secar berkelompok dengan anggota yang sama seperti pada pembelajaran sebelumnya. Lalu guru memberikan LKS yang harus dikerjakan oleh siswa secara berkelompok. Pertemuan sebelumnya guru telah meminta siswa untuk membawa data kependudukan dari desa tempat tinggal salah satu siswa di masing masing kelompok. Sebelum diskusi dimulai, guru menegaskan bahwa yang akan dinilai dalam diskusi adalah kekompakan kelopok, yang merupakan manfaat dari belajar dengan cooperative learning. Guru juga meminta bahwa siswa yang lebih mampu untuk selalu memberikan bantuan kepada yang kurang. Selain itu guru memberikan penegasan bahwa siapapun siswa yang ikut berpartisifasi dalam diskuci sekecil apapun pasti diberikan nilai, dan jangan pernah takut salah untuk berpendapat.

Tahap berikutnya mulailah siswa bekerja dalam kelompok, untuk menjawab pertanyaan dalam LKS. Selama siswa bekerja guru terus berkeliling memantau kerja tiap kelompok, memberi pujian kepada kelompok yang aktif dan tak lupa sekecil apapun kontribusi mereka selalu dinilai. Setelah diskusi kelopok selesai, maka tiap kelompok presentasi didepan kelas, ketika siswa presentasi didepan maka semua anggota kebagian tugas, sehingga yang berbicara bukan hanya ketua kelompok. Hal ini menunjuka nilai-nilai demokratis mulai berjalan. Hal ini tidak lepas dari peranan guru yang terus memotivasi semua siswa dalam pembelajaran untuk ikut aktif. Setelah semua siswa persentasi, maka dibagian akhir sebelum dilakukan post test, maka guru menguatkan lagi materi yang sudah dibahas, dengan membuat kesimpulan dan tidak lupa memberitahukan untuk materi pada pertemuan minggu berikutnya.

\section{c. Refleksi}

Pembelajaran Geografi di kelas X-1 SMA Negeri 3 Baubau, dengan menggunakan model cooperatif learning pada siklus ketiga sudah berhasil dengan baik. Hal ini terlihat dari adanya kelemahan atau kekurangan yang terjadi pada siklus kedua telah berhasil diperbaiki, sehingga secara umum tidak ditemui lagi dalam tindakan III. Sebagai gambaran, guru telah melaksanakan langkah-langkah pembelajaran secara sistematis, yang diawali dengan penjelasan materi yang akan dipelajari. Dalam penjelasannya guru juga menggunakan model yang variatif, dengan penggunaan media peta secara optimal. Sementara itu dalam tanya jawab, kesempatan bertanya atau menjawab diberikan secara merata bagi semua siswa.

Pemanfaatan waktu yang diberikan guru dalam diskusi juga secara efisien sudah dapat digunakan oleh setiap kelompok. Kerjasama antar anggota dalam kelompok juga sudah mampu dijalankan, sehingga terlihat siswa 


\section{SANG PENCERAH}

Volume 4, Nomor 1, Februari 2018, Hlm. 22-39

Mujurimi: Penerapan Model Pembelajaran Kooperatif ...

yang secara akademik pintar mau mambantu mereka yang kurang, sehingga dapat dipastikan bahwa permasalahan yang ada dalam LKS semua anggota mengetahui jawabannya. Nilai demokrasi sudah berhasil dimunculkan dengan melihat bagaimana siswa memberi kesempatan pada tiap anggota untuk menjawab permasalahan ketika dia presentasi di depan, ataupun ketika diskusi dalam kelompok, sehingga tidak ada lagi istilah bahwa diskusi hanya milik mereka yang pintar.

Hal ini sebagai indikator keberhasilan guru yang mampu bertindak sebagai motivator dan fasilitator serta evaluator yang baik bagi siswa. Pemberian reward berupa pujian ataupun iming-iming nilai ternyata telah mampu memotivasi hampir semua siswa untuk aktif dalam diskusi baik bertanya ataupun menjawab. Mereka tidak lagi merasa takut salah, karena yang penting dipuji, apalagi ketika mereka bertanya kemudian guru membahas lagi pertanyaan dengan menyebutkan penanyanya, maka siswa yang bertanya kelihatan sekali merasa dihargai dan berbangga hati. Berikut adalah hasil observasi pada siklus III pada kemampuan guru.

Tabel 7. Hasil Observasi Kemampuan Guru Dalam Pengembangan Bahan Ajar

Bentuk Kemampuan Guru

\begin{tabular}{|c|c|c|c}
\multicolumn{4}{c}{$\begin{array}{c}\text { Aspek yang } \\
\text { dicapai }\end{array}$} \\
\begin{tabular}{lllll} 
& \\
A & B & C & D & E \\
\hline
\end{tabular}
\end{tabular}

Memusatkan perhatian

a. Merumuskan masalah

b. Menjelaskan

manfaaatnya

c. Memberikan contohcontoh kongkrit

Merencanakan kegiatan siswa a. Membentuk kelompok b. Menjelaskan langkahlangkah kerja

Mengembangakan kemampuan siswa

a. Memeberikan

keleluasaan waktu

kepada siswa mengembangkan

kemampuannya.

b. Tidak cepat memotong pembicaraan

Meningkatkan motvasi siswa

a. Memberikan

pujian terhadap

individu atau

kelompok yang

berprestasi

Menyebarkan kesempatan berpartisipasi

b. Mengontrol aktivitas siswa

c. Mencegah pembicaraan yang berlebihan

d. Menghentikan monopoli pembicaraan

Menutup diskusi

a. Merangkum/menyi mpulkan

b. Memberi gambaran materi yang akan datang

Keterangan :

Keterangan:

$\mathrm{A}=$ seringkali dilakukan

$\mathrm{B}=$ sering dilakukan

$\mathrm{C}=$ kadang-kadang dilakukan

$\mathrm{D}=$ jarang dilakukan

$\mathrm{E}=$ jarang sekali dilakukan

Sementara itu, keberhasilan siswa dalam model pembelajaran cooperative learning dapat dilihat pada tabel berikut ini: 


\section{SANG PENCERAH}

Volume 4, Nomor 1, Februari 2018, Hlm. 22-39

\section{Mujurimi: Penerapan Model Pembelajaran Kooperatif ...}

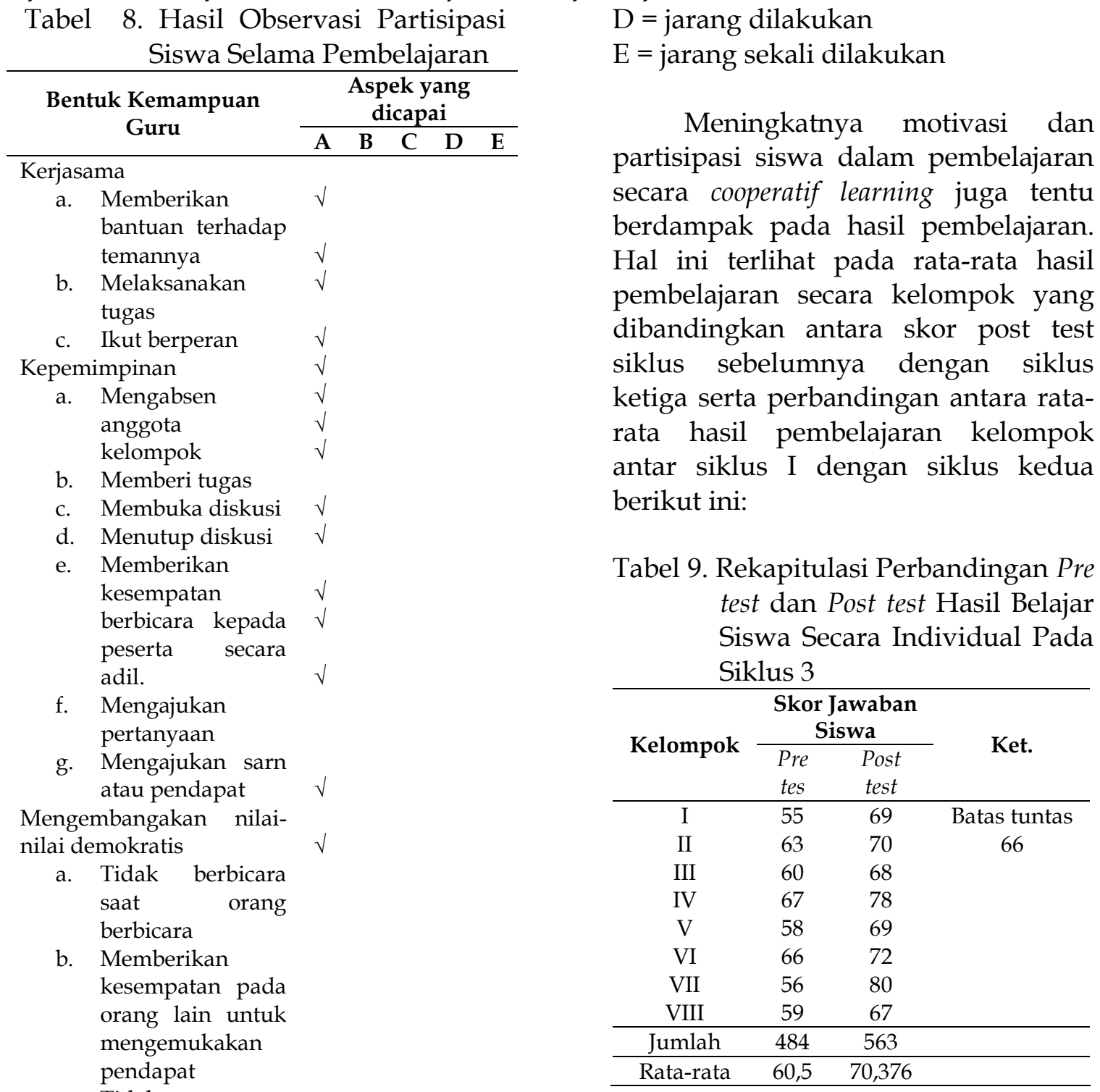

c. Tidak

menyalahkan

cecara langsung

apabila ada ide

yang kurang tepat

d. Menyelesaikan

tugas tepat waktu

Menghasilkan kreativitas

a. Media

pembelajaran

yang dapat

dipakai di kelas.

b. Media

pembelajaran

untuk digunakan

sendiri oleh siswa.

Keterangan:

A = seringkali dilakukan

$\mathrm{B}=$ sering dilakukan

$\mathrm{C}=$ kadang-kadang dilakukan

Tabel 10. Rekapitulasi Perbandingan Nilai Rata-rata Kelompok Pada Siklus I dan Siklus II dan III.

\begin{tabular}{ccccc}
\hline \multirow{2}{*}{ Kelompok } & \multicolumn{3}{c}{ Skor Jawaban Siswa } & \\
\cline { 2 - 4 } & $\begin{array}{c}\text { Siklus } \\
\text { I }\end{array}$ & $\begin{array}{c}\text { Siklus } \\
\text { II }\end{array}$ & $\begin{array}{c}\text { Siklus } \\
\text { III }\end{array}$ & Ket. \\
\hline I & 55 & 63 & 69 & Batas \\
II & 63 & 65 & 70 & tuntas \\
III & 60 & 62 & 68 & 66 \\
IV & 67 & 64 & 78 & \\
V & 58 & 68 & 69 & \\
VI & 66 & 67 & 72 & \\
VII & 56 & 56 & 80 & \\
VIII & 59 & 70 & 67 & \\
\hline Jumlah & 484 & 515 & 563 & \\
\hline Rata-rata & 60,5 & 64,38 & 70,376 & \\
\hline
\end{tabular}




\section{SANG PENCERAH}

Volume 4, Nomor 1, Februari 2018, Hlm. 22-39

\section{Mujurimi: Penerapan Model Pembelajaran Kooperatif...}

Berdasarkaan tabel rekapitulasi nilai rata-rata di atas, maka tergambar bahwa setelah dilakukan pembelajaran dengan model cooperatif learning pada siklus ketiga maka nilai siswa sudah mengalami ketuntasan berdasarkan criteria ketuntasan minimal (KKM), yang pada siklus I dan kedua belum tuntas. Nilai menunjukkan bahwa rata-rata nilai siswa hasil post test telah mencapai lenih dari 68,63. Berdasarkan hasil observasi atau pengamatan pada proses pembelajaran, dan berdasarkan hasil post test pada siklus tindakan ketiga, maka model pembelajaran cooperatif learning sudah berhasil dilaksanakan dengan indikator, motivasi dan partisipasi belajar meningkat serta nilai siswapun telah tuntas sesuai dengan kriteria. Hasil akhir pada siklus pembelajaran kedua juga telah menghasilkan kreativitas siswa berupa media pembelajaran yang dapat mempermudah mereka memahami persebaran flora dan fauna baik di dunia maupun di Indonesia.

Motivasi belajar siswa tidak hanya ditentukan oleh siswa itu sendiri, akan tetapi juga ditentukan oleh seorang guru dalam menerapkan model pembelajaran baik didalam maupun diluar kelas. Oleh karena itu, ketika menemukan situasi motivasi belajar siswa yang rendah yang berdampak pada pestasi belajar, guru yang profesional tidak serta merta memponis bahwa siswanya bodoh, akan tetapi guru akan mencari jalan keluar dengan menerapkan berbagai model pembelajaran. Hasil penelitian dikelas X-1 SMA Negeri 3 Baubau, menunjukan bahwa rendahnya motivasi dan hasil belajar yang selama ini hanya menggunakan model ceramah dan tanya jawab yang membosankan siswa, ternyata permasalahan dapat teratasi dengan penerapan salah satu model pembelajaran yaitu dengan model cooperative learning. Berdasarkan hasil penelitian, sistem pembelajaran dengan menggunakan model cooperative learning dapat meningkatkan efektifitas pembelajaran. Hal ini terbukti dari beberapa fakta berikut ini.

1. Motivasi Belajar Siswa

Berdasarkan data hasil penelitian, melalui penggunaan model pembelajaran cooperative learning, keseriusan siswa untuk belajar meningkat, yang ditunjukan oleh aktivitas mereka ketika guru menjelaskan dan ketika mereka diskusi, dimana mereka berusaha untuk bertanya, menjawab dan menanggapi permasalahan serta semua ikut andil menyelesaikan LKS yang ditugaskan pada setiap kelompok, sehingga jarang ditemukan siswa yang mengantuk aeperti ketika mendengar ceramah guru yang dianggap membosankan.

2. Efektifitas Pembelajaran

Pembelajaran dengan menggunakan model cooperative learning, terbukti cukup ampuh dalam mengaktifkan siswa sehingga dapat berubah pola teacher centered ke student centetered. Hal ini tidak terlepas dari strategi yang diterapkan baik dalam hal perencanaan, implementasi maupun evaluasi. Dalam proses perencanaan hasil sharing pendapat dengan rekan peneliti lain dan hasil observasi pada pembelajaran sebelumnya telah menjadi masukan yang sangat berarti dalam penyusunan perencanaan, sehingga dapat diambil tindakan kelas yang tepat dalam pembelajaran. Dalam proses implementasi atau pelaksanaan terhadap beberapa faktor yang mempengaruhi keberhasilan. Pertama, setiap kelompok adalah perpaduan antar 


\section{SANG PENCERAH}

Volume 4, Nomor 1, Februari 2018, Hlm. 22-39

\section{Mujurimi: Penerapan Model Pembelajaran Kooperatif ...}

anggota yang heterogen baik dari jenis kelamin maupun kemampuan akademik. Kedua, pemberian tugas yang lebih efektif yang disesuaikan dengan alokasi waktu dan sarana yang tersedia. Ketiga, kemampuan guru yang berhasil memposisikan diri sebagai fasilitator, motivator dan evaluator.

3. Aspek-aspek keberhasilan siswa

Aspek-aspek keberhasilan siswa sebagai akibat dari penggunaan cooperative learning, dapat ditinjau dari aspek keaktifan, motivasi dan hasil belajar. Ditinjau dari kreatifitas siswa, proses pembelajaran dengan cooperative learning telah mampu mengaktifkan sebagian besar siswa dalam belajar, sehingga siswa yang aktif dalam belajar bukan hanya milik siswa yang secara akademik tinggi, akan tetapi juga berhasil mengaktifkan siswa yang sebelumnya malas atau minder untuk bertanya, menjawab, atau berpendapat.

Dilihat dari aspek motivasi, model pembelajaran cooperative learning, telah mampu meningkatkan motivasi belajar siswa, sehingga mau mencari atau menanyakan jawaban dari permasalahan yang dihadapi kepada teman sekelompoknya. Motivasi tinggi juga dapat dilihat dari meningkatnya rasa keingintahuan mereka terhadap permasalahan, sehingga kadangkadang mereka kalau tidak puas bertanya di kelas, diluar kelas menanyakan kembali karena rasa penasaran terhadap fenomena geografis yang ada. Ditinjau dari aspek pretasi dan kreatifitas siswa, model pembelajaran cooperative learning, telah mampu meningkatkan hasil tes belajar siswa untuk mencapai kriteria ketuntasan minimal dibandingkan dengan hasil tes dengan model pembelajaran sebelumnya yang banyak dari siswa tidak mendapatkan nilai tuntas. Selain itu kreatifitas siswa juga muncul dengan menghasilkan beberapa hasil kreatifitas yang dapat dijadikan media pembelajaran, baik berbentuk peta persebaran flora dan fauna maupun bentuk kreatiftas lain yang dapat membantu mereka mempermudah dalam mengidentifikasi persebaran flora dan fauna. Aspek lain yang dihasilkan dari pembelajaran cooperative learning ini adalah prinsip getting better together yang memunculakn rasa kebersamaan, kekompakan rasa saling menghargai dengan berbagai perbedaan yang ada, dengan tetap bersaing secara sehat baik secara individu atau kelompok.

\section{Simpulan}

Simpulan penelitian ini bahwa melalui penelitian tindakan kelas yang dilakukan dalam penelitian ini berhasil mencapai tujuan penelitian yaitu dapat meningkatkan motifasi dan partisipasi siswa dalam belajar geografi. Keberhasilan ini tercermin dari hasil evaluasi proses dan evaluasi hasil belajar. Evaluasi proses ditunjukkan dengan meningkatkannya prestasi belajar yang semua telah mencapai tuntas berdasarkan kriteria yang ditentukan, evaluasi hasil juga telah berhasil menghasilkan salah satu bentuk hasil kreatifitas sederhana yang dapat digunakan sebagai media dalam pembelajaran. 


\section{SANG PENCERAH}

Volume 4, Nomor 1, Februari 2018, Hlm. 22-39

\section{Mujurimi: Penerapan Model Pembelajaran Kooperatif...}

\section{Daftar Pustaka}

Dahlah, M.D. 1984. Model-Model

Pembelajaran, Bandung: CV

Dipenogoro.

Musclich, Masnur. 2007. KTSP

(Pembelajaran Berbasis Kompetensi

Dan Konteksual), Jakarta: PT

Bumi Aksara.

Sanjaya, Wina. (2007). Strategi Pembelajaran Berorientasi Standar

Proses Pendidikan, Jakarta:

Kencana Prenada Media Group.

Sukmadinata, N.Sy. (2004). Kurikulum

Dan Pembelajaran Kompetensi,

Bandung: PT Remaja

Rosdakarya.

(2004). Pengembangan

Kurikulum Teori dan Praktek,

Bandung: PT Remaja

Rosdakarya.

Yasmin, Martinis (2006) Strategi Pembelajaran Berbasis Kompetensi, Jakarta: Gaung Persada Press Jakarta. 
SANG PENCERAH

Volume 4, Nomor 1, Februari 2018, Hlm. 22-39

Mujurimi: Penerapan Model Pembelajaran Kooperatif ... 